\title{
Microwave Boriding to Improve the Corrosion Resistance of AISI 304L Austenitic Stainless Steel
}

\section{Dilek ARSLAN ${ }^{1 *}$, Recep Onur UZUN ${ }^{2}$}

\begin{abstract}
In this study, the corrosion behaviors of AISI 304L austenitic stainless steel samples were subjected to pack-boriding at 850,900 and $950{ }^{\circ} \mathrm{C}$ process temperatures for 2,4 and 6 hours with microwave hybrid heating, and examined. Boride layers were characterized by optical microscope and $\mathrm{XRD}$. As a result of XRD analyses, the presence of $\mathrm{FeB}, \mathrm{Fe}_{2} \mathrm{~B}, \mathrm{Cr}_{2} \mathrm{~B}$ and $\mathrm{Ni}_{2} \mathrm{~B}$ compounds in the boride layers were determined formed on the sample surfaces. As an alternative to conventional heating, AISI 304L austenitic stainless steel samples subjected to pack-boriding with microwave hybrid heating, as a result of the corrosion tests carried out during the $3^{\text {rd }}, 7^{\text {th }}$ and $10^{\text {th }}$ days in $2 \% \mathrm{~V} / \mathrm{V}$ (for volume per volume) HNO3 acid solution, the corrosion resistance of the AISI 304L austenitic stainless steel samples as loss in mass increased with the increase in the temperature and duration of the boriding process and the corrosion resistance increased 95 times compared to the untreated AISI 304L stainless steel samples.
\end{abstract}

Keywords: microwave hybrid heating, austenitic stainless steel, pack-boriding, corrosion resistance

'Dilek ARSLAN (Orcid ID: 0000-0003-0198-0787), Graduate School of Applied and Natural Sciences, Department of Mechanical Engineering, Manisa Celal Bayar University, Martyr Prof. Dr. İlhan Varank Campus, Yunusemre, Manisa, Turkey

${ }^{2}$ Recep Onur UZUN (Orcid ID: 0000-0002-1042-0493), Hasan Ferdi Turgutlu Faculty of Technology, Department of Mechanical Engineering, Manisa Celal Bayar University, Manisa, Turkey

*Sorumlu Yazar/Corresponding Author: Dilek ARSLAN, e-mail: da.dilekarslan@gmail.com

Bu çalışma Dilek ARSLAN'ın Doktora tezinden üretilmiştir. 


\section{INTRODUCTION}

The challenging working conditions brought about by the developing technology shorten the life of steel material used in almost every area of the industry and lead to great economic losses. The concern about how to extend the service life of steel material, which has taken place in many fields, and how to increase corrosion resistance, especially the applications requiring high corrosion resistance, has made surface treatments a trending engineering application of recent years. Boriding on these surface treatments is widely used due to its high effect on improving the mechanical properties and corrosion resistance of metals and alloys, its easy applicability, the fact that it does not require a complex assembly and being a relatively economical method. The boriding process takes place at temperatures between 850 and $1000{ }^{\circ} \mathrm{C}$ for holding times between 1 and 10 hours. The most important feature of the method is the production of layers with surface hardness that can exceed $20 \mathrm{GPa}$; it provides better wear resistance than other thermochemical surface treatments such as boriding, carburizing and nitriding (Von Matushka, 1980). There are boriding methods in solid, liquid, gas environments as well as salt melt and plasma environments as a boron providing medium. However, due to the difficulty of process technologies, high initial investment need and environmental risks, it has not yet gained sufficient prevalence. Currently, boriding in solid media is the most preferred method (Campos-Silva, 2010). As a result of this thermochemical surface treatment, which is based on the diffusion of the boron to the material surface, the material surface is coated with a high rigidity boride layer adhering to the substrate with high adhesion power (Davis, 2001). Thus, boriding process increases the corrosion and abrasion resistance of these surfaces coated with boride layers (Gunes, 2013; Ozbek \& Bindal, 2002). Erdogan and Gunes used Ekabor-II boriding powder on high alloy cold work tool steel for 6 hours at 850 and 950 ${ }^{\circ} \mathrm{C}$ temperatures. The surface hardness of the samples with a microhardness of $428 \mathrm{HV}_{0.05}$ reached 1806$2342 \mathrm{HV}_{0.05}$ after boriding process. Corrosion resistance of boronized samples to $4 \% \mathrm{M} \mathrm{HCl}$ acid solution was 8-17 times increased (Erdogan \& Gunes, 2015). Günen et al. has subjected AISI H13 hot work tool steel to pack-boriding process for 2, 4 and 6 hours at 800,900 and $1000{ }^{\circ} \mathrm{C}$ temperatures and concluded that corrosion resistance of boronized AISI H13 steel to $3.5 \% \mathrm{NaCl}$ solution increased 33.5 times (Günen, 2020). Ergun et al. has examined the corrosion behaviors of AISI 420 and AISI 5120 steels boronized by pack-boriding method in Ekabor-II powder at $950{ }^{\circ} \mathrm{C}$ for 5 hours in $4 \% \mathrm{M} \mathrm{HCI}$ acid solution. The results of the study showed that the corrosion resistance of boronized steels increased 6-8 times compared to untreated steels (Ergun, 2017). Erdoğan et al. has examined the corrosion behaviors of GS18Ni-MoCr36 (GS 18) and GS32NiCrMo6.4 (GS 32) gear steels boronized in Ekabor-II powder at $950{ }^{\circ} \mathrm{C}$ for 2 and 6 hours and found a 5.5 and 4.5 times increase in surface hardness and a 4-6 times increase in corrosion resistance of GS 18 and GS 32 gear steels after boriding, respectively (Erdoğan, 2014). A similar increase in corrosion resistance was obtained in AISI M2 steel in another study. Gunes et al. has concluded that AISI M2 steel, which they applied pack-boriding with Ekabor-II powder at 950 ${ }^{\circ} \mathrm{C}$ and with a holding time of 6 hours, showed 4-6 times more corrosive resistance to $4 \% \mathrm{M} \mathrm{HCI}$ acid (Gunes, 2014). Günen et al. has applied pack-boriding to AISI 304 austenitic stainless steel using 10-50 $\mathrm{nm}$ Nanoboron powder at temperatures ranging from $950{ }^{\circ} \mathrm{C}$ to $1000{ }^{\circ} \mathrm{C}$ with 2 to 4 hours of boriding time. Corrosion tests performed in $10 \% \mathrm{H}_{2} \mathrm{SO}_{4}$ acid solution showed that corrosion resistance of boronized samples increased approximately 4.3-fold against acid solution (Gunen, 2014).

Austenitic stainless steels are the most widely used stainless steel type in all branches of industry, architectural applications, numerous areas such as domestic products and medical equipment thanks to their easy plasticity, high welding capabilities, being used at very high temperatures and their mechanical strength. Despite this, the aggressive working environments of the increasing technology also deform 
these steels. For this reason, remedial metallurgical treatments should be applied to austenitic stainless steels such as other stainless steel types whose corrosion resistance and mechanical strength are increased by various heat treatments. However, these steels cannot be hardened by heat treatment as they protect their austenitic microstructures with face-centered cubic lattice at both room temperature and high temperatures. For this reason, boriding helps austenitic stainless steels in this regard. Mertgenc et al. has boronized AISI 303 austenitic stainless steel by pack boriding method at $1123 \mathrm{~K}, 1173 \mathrm{~K}$ and $1223 \mathrm{~K}$ for 2, 4 and $6 \mathrm{~h}$. As a result of the boriding process, the hardness of the material increased by approximately 8 times, and the wear resistance improved approximately 11 times (Mertgenc, 2019). Kayali et al. has investigated the effect of pack-boronizing on corrosion resistance of the coated samples. AISI 316L austenitic stainless steel samples were boronized in a solid medium using Ekabor 2 powders at $800{ }^{\circ} \mathrm{C}$ and $900{ }^{\circ} \mathrm{C}$ for $2 \mathrm{~h}$ and $6 \mathrm{~h}$. Although the expected improvement in corrosion resistance has not been achieved, the corrosion resistance is at acceptable values in a simulation body fluid (Kayali, 2013). Although increasing corrosion resistance by boriding such stainless steels with good corrosion resistance in oxidizing or reducing mediums has begun to attract attention in recent years, studies are limited with the corrosion resistance of steels pack-borided with microwave heating in the literature. AISI P20 steel was subjected to the microwave boronizing treatment on at 800,850 and $900{ }^{\circ} \mathrm{C}$ temperatures for a retention time of 2,4 , and $6 \mathrm{~h}$. An improvement in the corrosion resistance of AISI P20 steel was seen with microwave boronizing heat treatment (Kayali, 2018). In this study, the corrosion behavior was examined on AISI 304L austenitic stainless steel material which was subjected to packboriding by microwave hybrid heating as an alternative to conventional heating in $2 \% \mathrm{~V} / \mathrm{V} \mathrm{HNO}_{3}$ acid solution. In addition to this goal, in this study, it was aimed to improve corrosion resistance of AISI 304L austenitic stainless steel material against acidic environment with boriding whose thermal diffusion performance was increased by using microwave hybrid heating in the pack-boriding process.

\section{MATERIALS AND METHODS}

\section{Microwave boriding and characterization}

The pack-boriding process with microwave hybrid heating was conducted on cylindrical samples of AISI 304L austenitic stainless steel. The chemical composition of this steel is: $\leq 0.030 \mathrm{wt} . \% \mathrm{C}, \leq$ 2.00 wt. $\% \mathrm{Mn}, \leq 0.045$ wt. $\% \mathrm{P}, \leq 0.030$ wt. $\% \mathrm{~S}, \leq 0.75$ wt. $\% \mathrm{Si}, 18-20$ wt. $\%$ Cr, $8-10$ wt. $\% \mathrm{Ni}, \leq$ 0.10 wt. $\%$ N. The test specimens were cut into $\varnothing 20 \times 10 \mathrm{~mm}$ dimensions, ground up to 1200 grid, afterwards cleaned by sonicating for 30 minutes in acetone and dried in the open air. The pack-boriding was carried out in a solid medium containing an Ekabor-II powder mixture placed in a microwave sintering furnace operated up to the temperature of $1200^{\circ} \mathrm{C}$ under argon gas. The temperature increase has been entered into the system of the microwave sintering furnace as $15^{\circ} \mathrm{C} / \mathrm{min}$. Test specimens were embedded in sealed AISI 304 stainless steel crucibles together with the Ekabor-II powder mixture. Pictures of the microwave hybrid heating setup, furnace chamber and pack-boriding crucibles using the microwave sintering furnace to perform the pack-boriding process are shown in Figure 1. Boriding was carried out at 850,900 and $950{ }^{\circ} \mathrm{C}$ for 2,4 and 6 hours. In microwave heating methods, there is no nonhomogeneous heating problem since volumetric and homogeneous heating occurs from the inside out. Moreover, thanks to the heat transfer by radiation, due to the efficient conversion of energy and the homogeneity of the temperature distribution in the reaction vessel, reaction rates and product yield increase (Shen, 2011). Microwave heating has proven itself in different methods that it has advantages in terms of both process performance and energy saving. In sintering using microwave heating, it was determined that the mechanical properties of samples were better than conventional sintered samples, and up to $60 \%$ energy savings were achieved in microwave sintering (Yönetken, 2019). It was observed 
that thickness and surface hardness of boride layer formed on the surface of borided samples in the microwave furnace higher than that of borided samples in the conventional furnace (Kayali, 2015). In the pack-boriding process where conventional furnace is used as the heat source is called conventional heating. In this study, microwave hybrid heating is called because heat transfers occur by conduction and convection mechanisms together with microwave radiation. After the boriding processes were completed, the samples were removed from the closed crucibles and allowed to cool in the open air. The microstructures of polished and etched cross-sections of the specimens were examined under an optical microscope that is Nikon Eclipse LV150N brand. Boride layer thickness measurements were performed with the Clemex analysis system. Hardness measurements were carried out with the Future-Tech FM 700 brand device. The presence of boride compounds formed in the boride layer was confirmed by means of $\mathrm{X}$-ray diffraction equipment using $\mathrm{Cu} \mathrm{K} \alpha$ radiation.

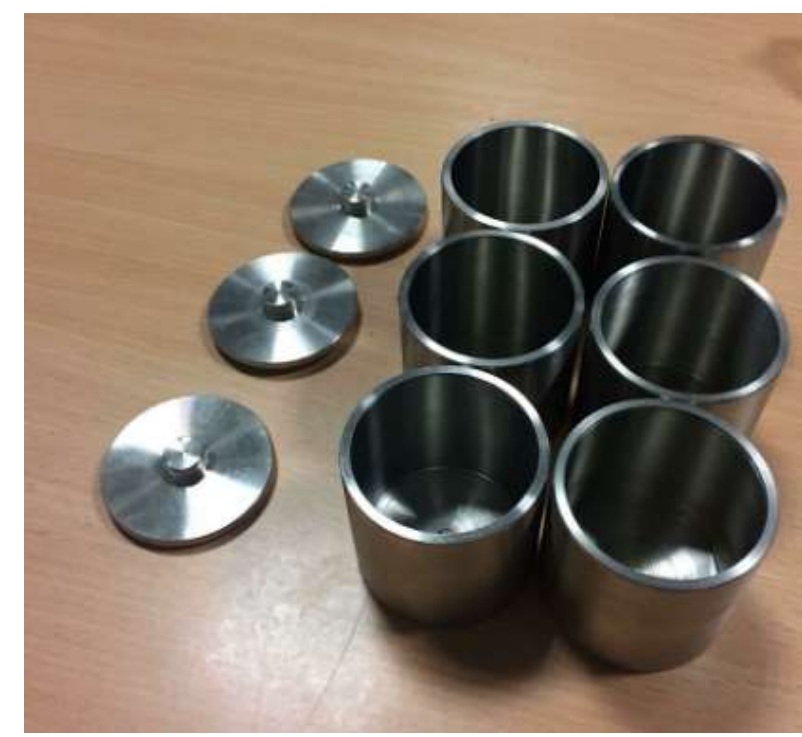

(a)

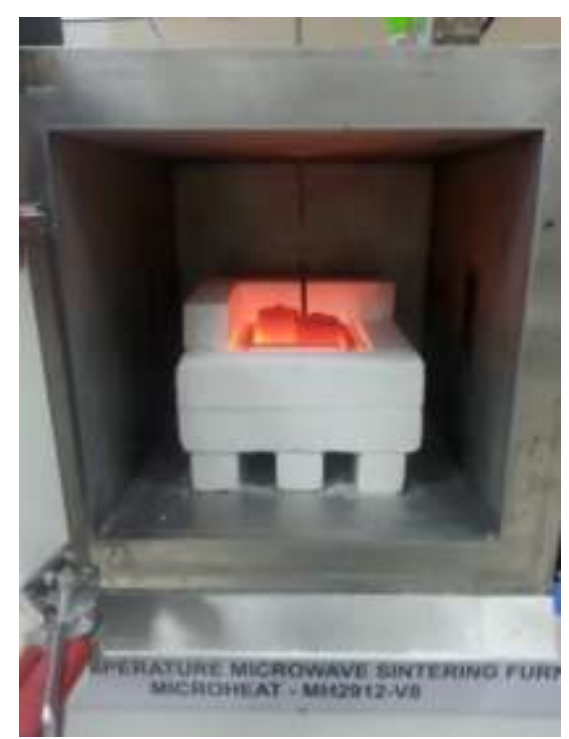

(b)

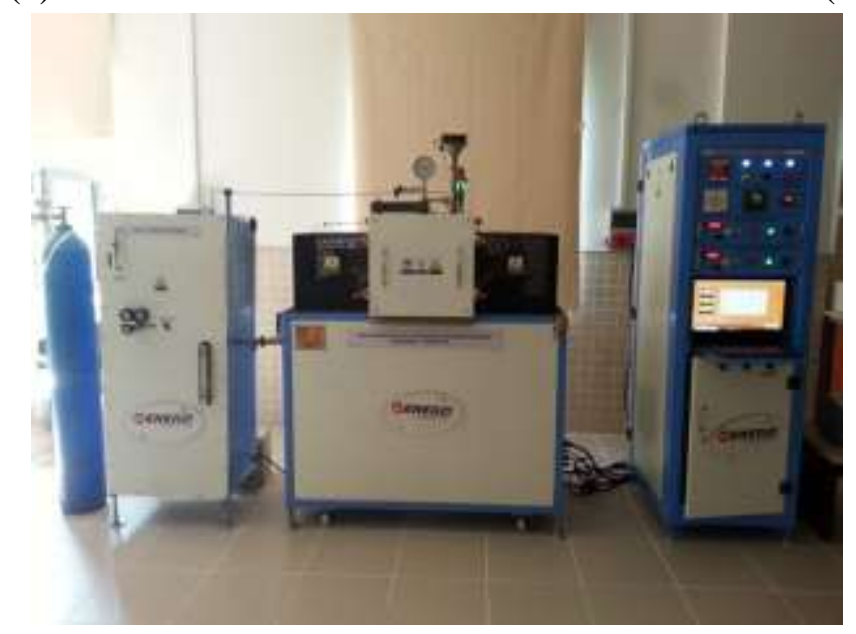

(c)

Figure 1. (a) Pack-boriding crucibles, (b)Furnace chamber, (c) Microwave hybrid heating setup

\section{Corrosion Test}

While the corrosion resistance of boride layers against alkaline medias is very high; it is known to be lower against oxidizing acidic medias. For this reason, corrosion tests are generally carried out in 
acidic medias such as $\mathrm{HNO}_{3}, \mathrm{H}_{2} \mathrm{SO}_{4}, \mathrm{HClO}_{4}$ etc. In this study, AISI 304L stainless steel samples applied pack-boriding for 2,4 and 6 hours at $850{ }^{\circ} \mathrm{C}, 900{ }^{\circ} \mathrm{C}$ and $950{ }^{\circ} \mathrm{C}$ process temperatures by microwave heating method were kept in $2 \% \mathrm{~V} / \mathrm{V} \mathrm{HNO}_{3}$ solution for corrosion tests; at the end of the $3^{\text {rd }}, 7^{\text {th }}$ and $10^{\text {th }}$ days, loss in mass was measured with a precision balance. The measurement of the loss in mass was made with the balance of Sartorius brand with a precision of $0.0001 \mathrm{~g}$ in Figure 2. The samples kept in $2 \% \mathrm{~V} / \mathrm{V} \mathrm{HNO}_{3}$ solution are shown in Figure 3. Surface examinations of the samples were performed with Nikon SMZ-745T brand stereo microscope seen in Figure 4 at the end of the $10^{\text {th }}$ day.

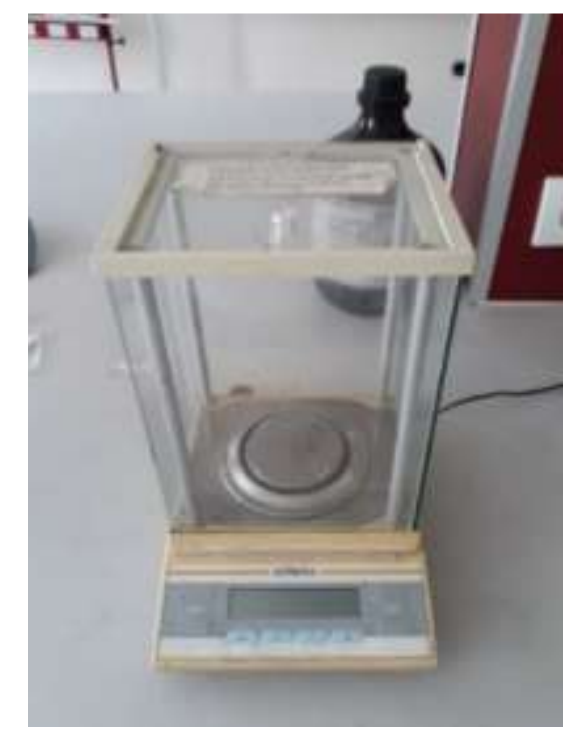

Figure 2. The balance of Sartorius brand

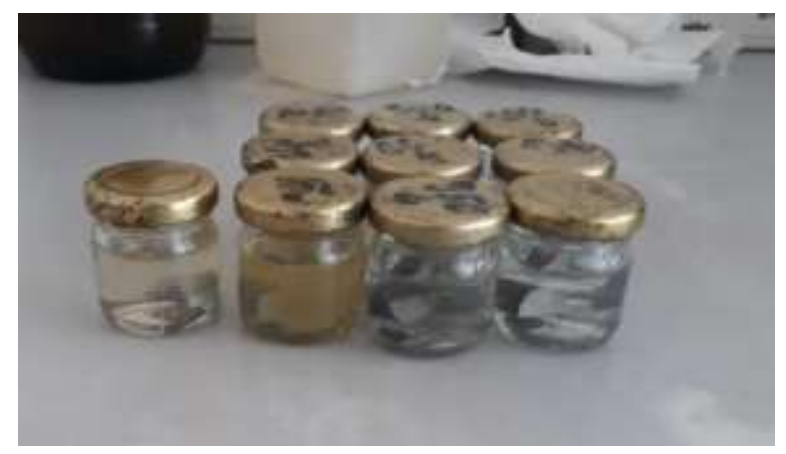

Figure 3. The samples kept in $2 \% \mathrm{HNO}_{3}$ solution

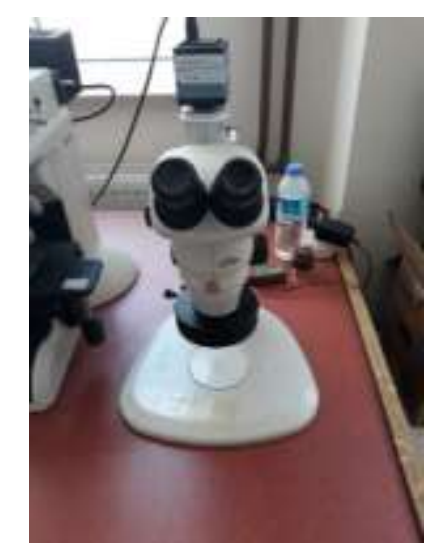

Figure 4. The stereo microscope of Nikon SMZ-745T brand 


\section{RESULTS AND DISCUSSION}

\section{Characterization of Boride Coatings}

Cross-sectional views of the pack-borided AISI 304L austenitic stainless steel are shown in Fig. 5. As can be seen, the borides that form on the AISI 304L austenite stainless steel has a smooth and flat morphology due to the higher content of alloy elements especially $\mathrm{Cr}$ and $\mathrm{Ni}$ (Mertgenc, 2019). Because the alloy elements affect the diffusion of boron atoms and determine the morphology of the boride layer/matrix interface. The increase in the amount of alloy element flattens the boride layer/ substrate interface (Ozbek, 2002). Microstructural examination of the surfaces showed the presence of a FeB/Fe ${ }_{2} \mathrm{~B}$ bilayer boride layers. The boride layer/matrix interface and matrix could be significantly distinguished and the boride layer had a compact and flat structure. Boride layer thicknesses of 9,11-13,27 $\mu \mathrm{m}, 13,89$ $22,10 \mu \mathrm{m}, 18,48-39,97 \mu \mathrm{m}$ respectively have been obtained in the process times at $850{ }^{\circ} \mathrm{C}, 900{ }^{\circ} \mathrm{C}, 950$ ${ }^{\circ} \mathrm{C}$ on the sample surfaces pack-borided by conventional heating. Boride layer thicknesses of the sample surfaces pack-borided by microwave heating have been measured 12,14-28,93 $\mu \mathrm{m}, 16,35-43,71 \mu \mathrm{m}$, $29,86-56,68 \mu \mathrm{m}$ respectively in different process times $850{ }^{\circ} \mathrm{C}, 900{ }^{\circ} \mathrm{C}, 950{ }^{\circ} \mathrm{C}$. After the pack-boriding conducted by conventional heating, the surface hardness of the samples was in the range of 400.3-1457.8 $\mathrm{HV}_{0.05}$; hardness values in the range of 980.4-2074.8 $\mathrm{HV}_{0.05}$ have reached by microwave heating. XRD analyses were performed on the surfaces of the pack-borided AISI 304L austenitic stainless steel samples, and revealed the presence of the $\mathrm{FeB}, \mathrm{Fe}_{2} \mathrm{~B}, \mathrm{Cr}_{2} \mathrm{~B}$ and $\mathrm{Ni}_{2} \mathrm{~B}$ compounds in Fig. 6. There are $\mathrm{FeB}, \mathrm{Fe}_{2} \mathrm{~B}, \mathrm{Cr}_{2} \mathrm{~B}$ and $\mathrm{Ni}_{2} \mathrm{~B}$ peaks in the boride layer formed on all samples.

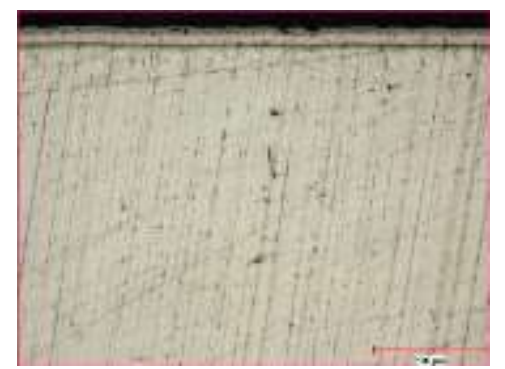

$850{ }^{\circ} \mathrm{C}-2 \mathrm{~h}$

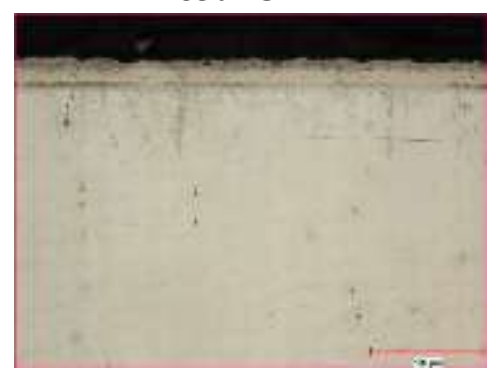

$900{ }^{\circ} \mathrm{C}-2 \mathrm{~h}$

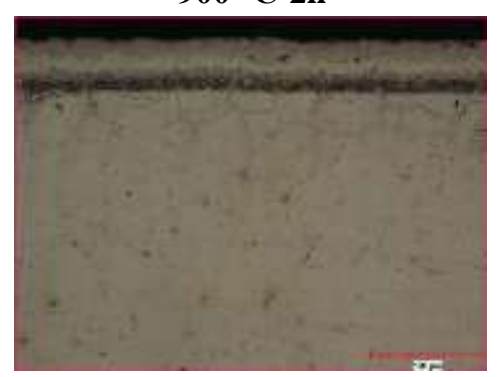

$950{ }^{\circ} \mathrm{C}-2 \mathrm{~h}$

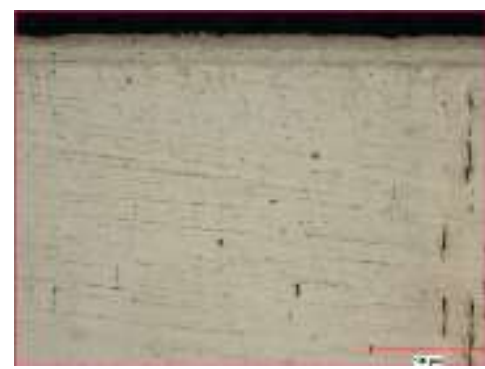

$850{ }^{\circ} \mathrm{C}-4 h$

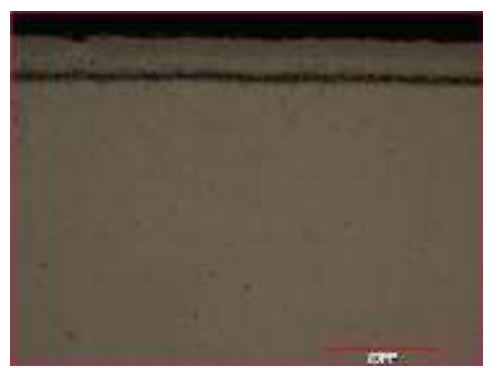

$900{ }^{\circ} \mathrm{C}-4 \mathrm{~h}$

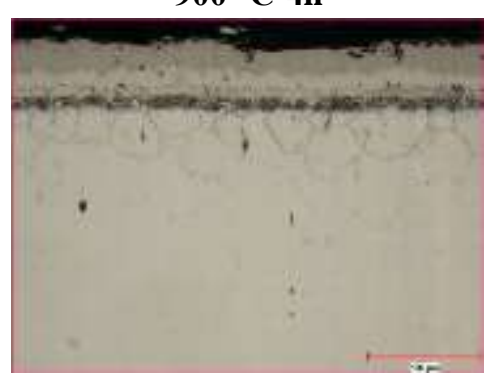

$950{ }^{\circ} \mathrm{C}-4 \mathrm{~h}$

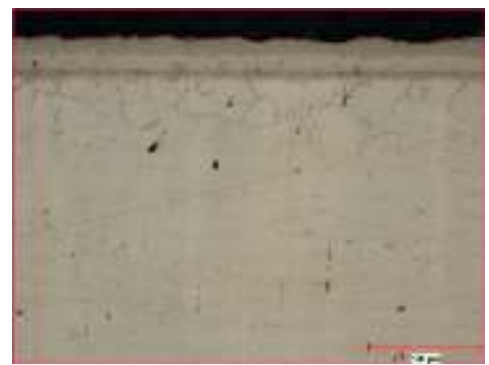

$850{ }^{\circ} \mathrm{C}-6 \mathrm{~h}$

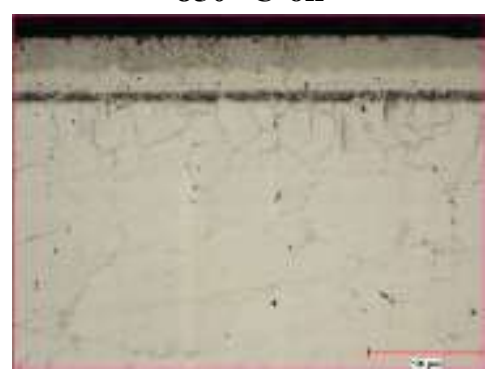

$900{ }^{\circ} \mathrm{C}-6 \mathrm{~h}$

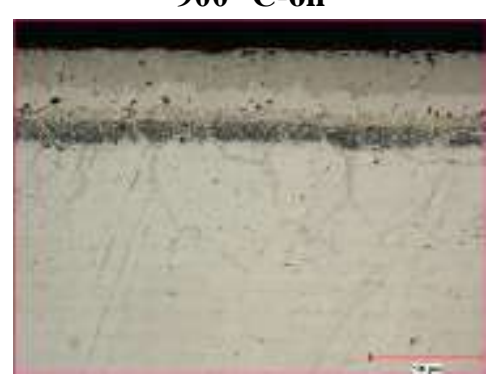

$950{ }^{\circ} \mathrm{C}-6 \mathrm{~h}$

Figure 5. Microstructural images of AISI $304 \mathrm{~L}$ pack-borided at process temperatures and times with microwave hybrid heating 


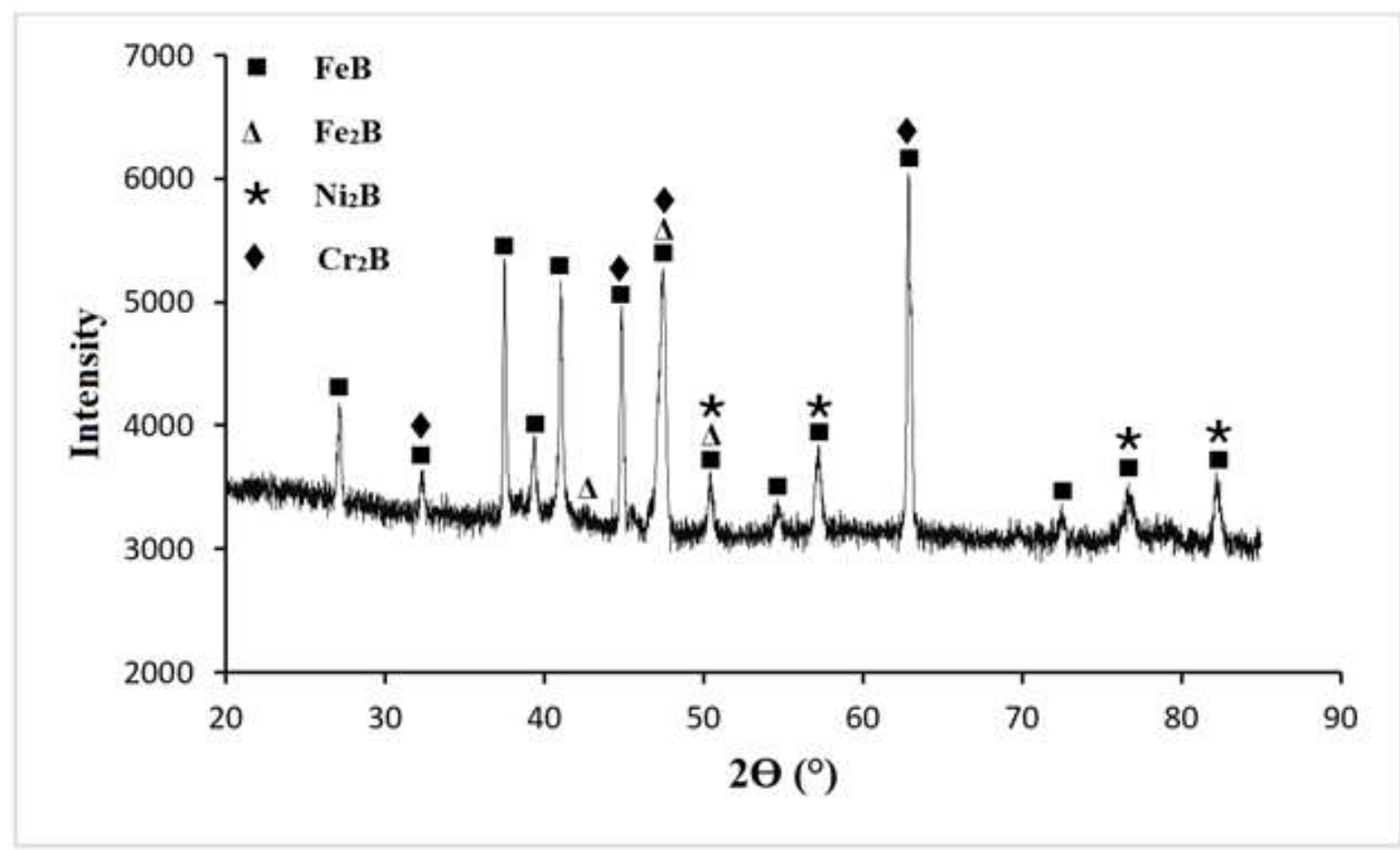

Figure 6. The XRD pattern of sample pack-borided at $950{ }^{\circ} \mathrm{C}$ for 4 hours with microwave hybrid heating

\section{Corrosion Resistance}

Figure 7 shows a macro image of the unboronized AISI 304L austenitic stainless steel sample, and pitting corrosion occurred almost all over the surface at the end of the $10^{\text {th }}$ day of immersing in $2 \% \mathrm{~V} / \mathrm{V}$ $\mathrm{HNO}_{3}$ solution. Figure 8 shows the macro images of AISI 304L stainless steel samples subjected to pack-boriding for 2, 4 and 6 hours at 850,900 and $950{ }^{\circ} \mathrm{C}$ process temperatures by microwave hybrid heating method after corrosion test at the end of the $10^{\text {th }}$ day of immersing in $2 \% \mathrm{~V} / \mathrm{V} \mathrm{HNO}_{3}$ solution. It is seen that the increase in boriding process temperature and duration also increases corrosion resistance. It is seen that the boride layer is completely corroded in the pit areas. Corrosion resistance is moderate in samples pack-borided at $900{ }^{\circ} \mathrm{C}$ for 4 hours and $950{ }^{\circ} \mathrm{C}$ for 2 hours. However, insufficient boride layer thickness in other samples could not protect the sample against corrosion. Corrosive protection was provided exactly in the sample pack-borided at $900{ }^{\circ} \mathrm{C}$ for 6 hours. Protection against corrosion could not be provided in samples with a thickness below $43.72 \mu \mathrm{m}$, which is the average boride layer thickness of this sample $\left(900^{\circ} \mathrm{C}-6 \mathrm{~h}\right)$. Boride layer thicknesses could not be obtained at this value by conventional heating method. AISI 304L samples pack-borided with microwave hybrid heating at 900 ${ }^{\circ} \mathrm{C}$ for 6 hours, $950{ }^{\circ} \mathrm{C}$ for 4 and 6 hours showed full resistance to corrosion. In fact, the corrosion resistance of the sample pack-borided at $950{ }^{\circ} \mathrm{C}$ for 6 hours increased 95 times. While the corrosion resistance of the austenitic stainless steel material exhaust pipe is increased by $85 \%$ by the plasma spray coating method, which is a relatively more complex and costly method (Sap, 2020); as a result of packboriding with microwave hybrid heating, corrosion resistance reached $95 \%$ with a more economical and simple process. In Figure 9, the graph showing the loss in mass in the per unit area $\left(\mathrm{cm}^{2}\right)$ at the end of the $3^{\text {rd }}, 7^{\text {th }}$ and $10^{\text {th }}$ days of AISI 304L stainless steel samples kept in $2 \% \mathrm{~V} / \mathrm{V} \mathrm{HNO} 3$ solution is given. 


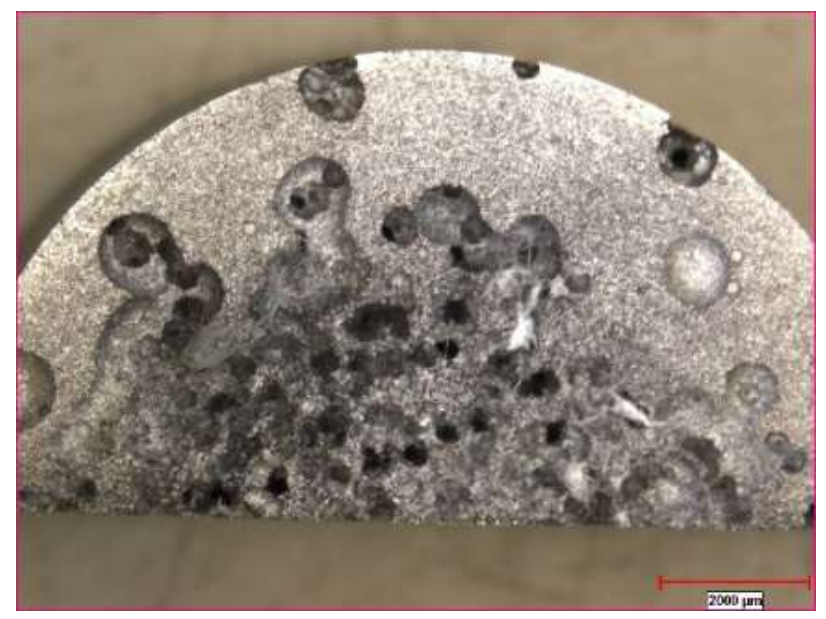

Figure 7. Image of untreated AISI 304L sample after corrosion test (at the end of the $10^{\text {th }}$ day)

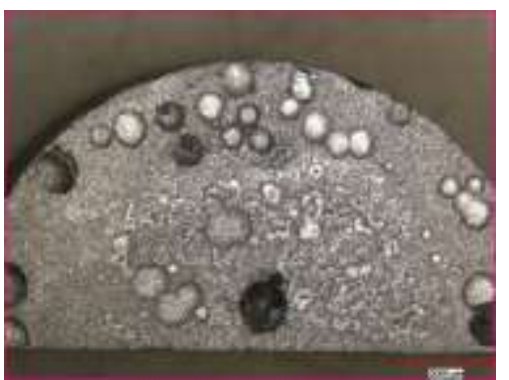

$850{ }^{\circ} \mathrm{C}-2 \mathrm{~h}$

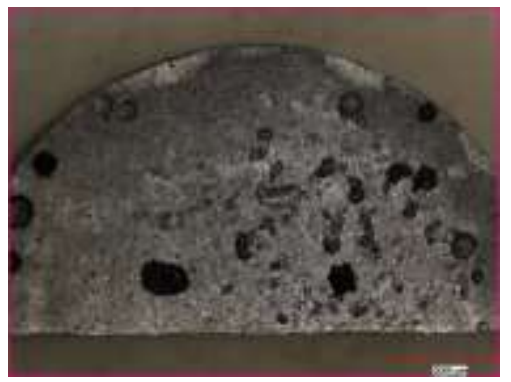

$900{ }^{\circ} \mathrm{C}-2 \mathrm{~h}$

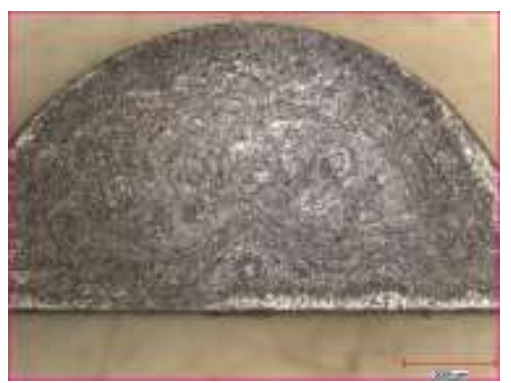

$950{ }^{\circ} \mathrm{C}-2 \mathrm{~h}$

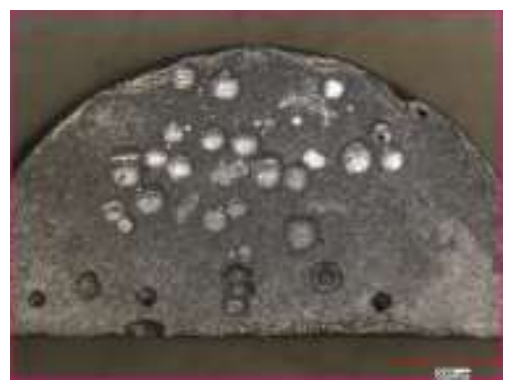

$850{ }^{\circ} \mathrm{C}-4 \mathrm{~h}$

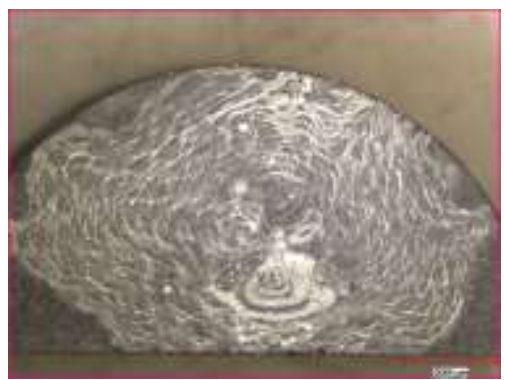

$900{ }^{\circ} \mathrm{C}-4 \mathrm{~h}$

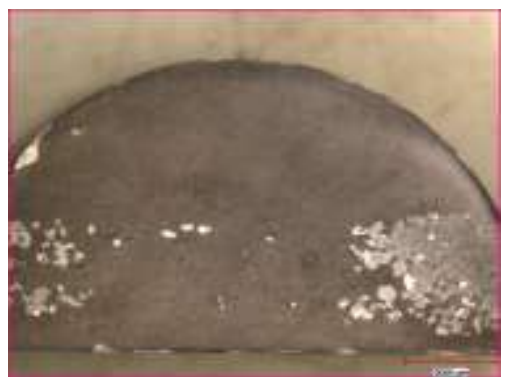

$950{ }^{\circ} \mathrm{C}-4 \mathrm{~h}$

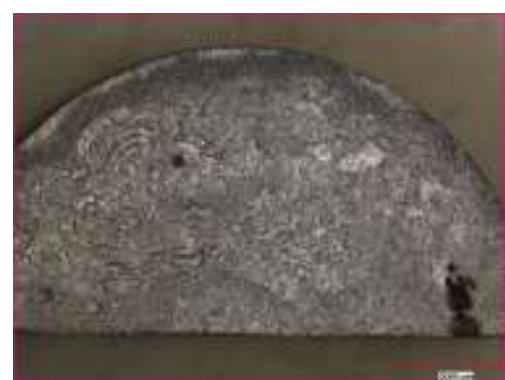

$850{ }^{\circ} \mathrm{C}-6 \mathrm{~h}$

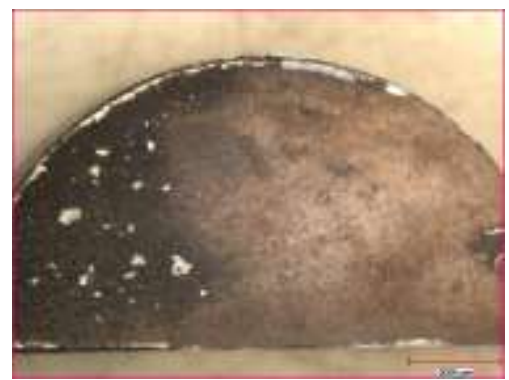

$900{ }^{\circ} \mathrm{C}-6 \mathrm{~h}$

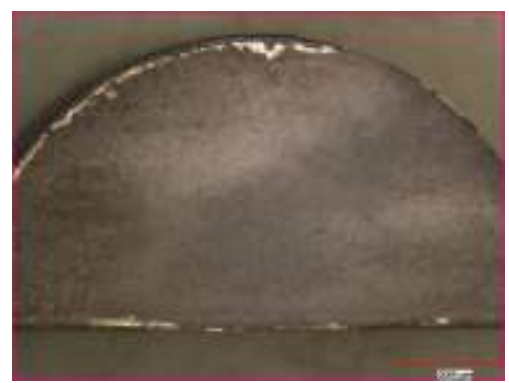

$950{ }^{\circ} \mathrm{C}-6 \mathrm{~h}$

Figure 8. Images of AISI 304L samples pack-borided with microwave hybrid heating after corrosion test (at the end of the $10^{\text {th }}$ day) 


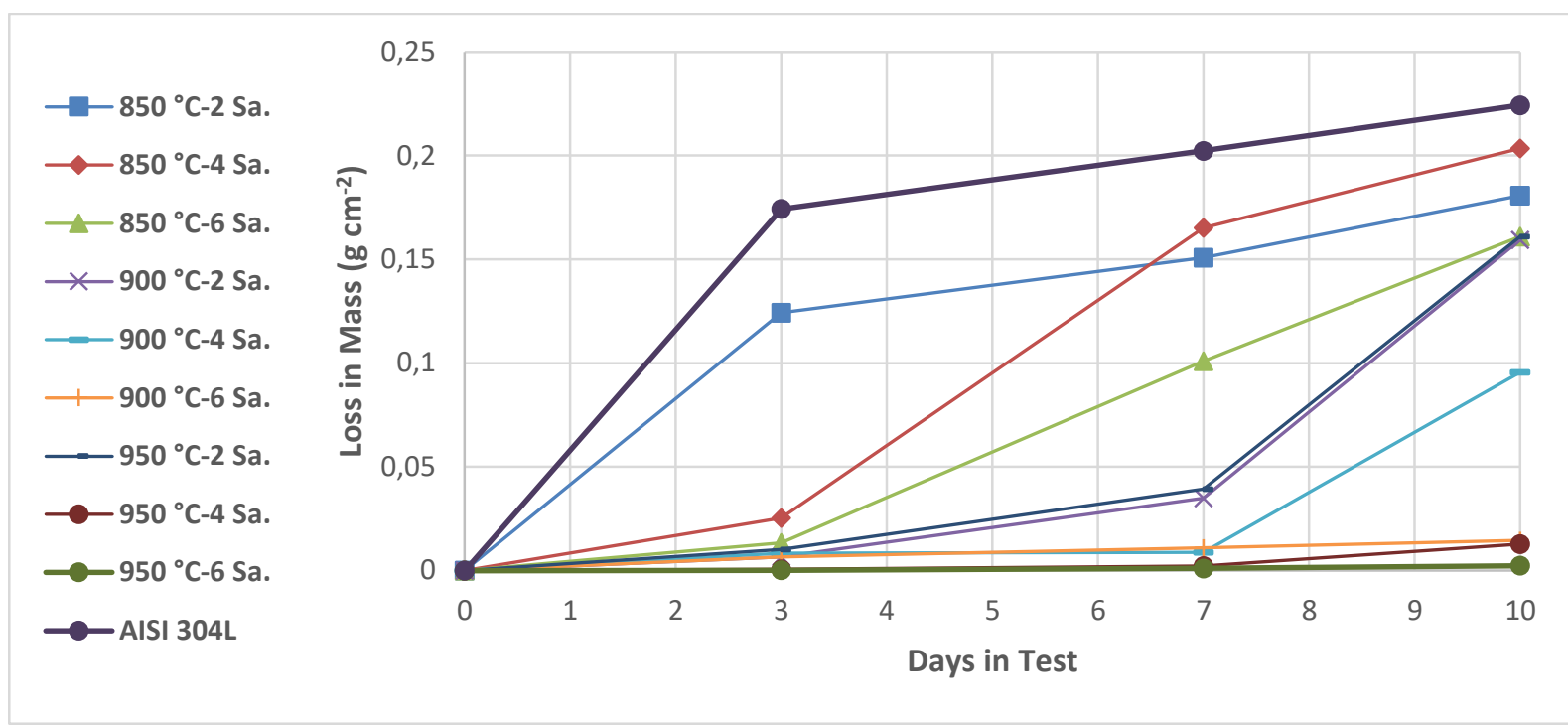

Figure 9. Loss in mass of AISI 304L samples pack-borided with microwave hybrid heating after corrosion test

\section{CONCLUSIONS}

- In the results of metallographic examinations, it was observed that the boride layer/base material interface morphology was formed in a flat, compact and smooth structure due to the high alloy content in the chemical composition of AISI 304L austenitic stainless steel material.

- As a result of XRD pattern analyses, $\mathrm{FeB}, \mathrm{Fe}_{2} \mathrm{~B}, \mathrm{Cr}_{2} \mathrm{~B}$ and $\mathrm{Ni}_{2} \mathrm{~B}$ compounds were detected on the surface of AISI 304L austenitic steel material after pack-boriding with microwave hybrid heating.

- As a result of the corrosion tests carried out during the $3^{\text {rd }}, 7^{\text {th }}$ and $10^{\text {th }}$ days in $2 \% \mathrm{~V} / \mathrm{V} \mathrm{HNO}$ solution of samples pack-borided with microwave hybrid heating, it was observed that the corrosion resistance of AISI 304L stainless steel sample as loss in mass increased with the increase in the temperature and duration of the boriding process. Full corrosion resistance was determined in samples pack-borided at $900^{\circ} \mathrm{C}$ for 6 hours, at $950{ }^{\circ} \mathrm{C}$ for 4 and 6 hours. Based on these samples, the minimum boride layer $\left(\mathrm{FeB}+\mathrm{Fe}_{2} \mathrm{~B}\right)$ thickness required for corrosion resistance is $43.72 \mu \mathrm{m}$. This thickness could not be reached in samples pack-borided with conventional heating. It was observed that the corrosion resistances of the samples pack-borided with microwave hybrid heating for 6 hours at $950{ }^{\circ} \mathrm{C}$ with the highest corrosion resistance were 95 times higher than the untreated AISI 304L stainless steel alloy.

\section{REFERENCES}

Campos-Silva I, Ortiz-Dominguez M, Martínez-Trinidad J, López-Perrusquia N, Hernández-Sánchez E, Ramírez-Sandoval G, Escobar-Galindo R, 2010. Properties and Characterization of Hard Coatings Obtained by Boriding. Defect and Diffusion Forum, 297-301: 1284-1289.

Davis JR, 2001. Surface Engineering for Corrosion and Wear Resistance. (1st ed.). ASM International. Materials Park, OH. (Chapter 5).

Erdoğan M, Gunes I, Dalar A, 2014. Investigation of Corrosion Behavior of Borided Gear Steels. Transactions of the Indian Institute of Metals, 67(2): 291-297.

Erdogan M, Gunes I, 2015. Corrosion Behavior and Microstructure of Borided Tool Steel. Matéria (Rio de Janeiro), 20(2): 523-529. 
Ergun Y, Gunes I, Erdoğan M, Cankaya N, 2017. Effect of Boriding Treatment on the Corrosion Behavior of Steels. Journal of Nanoscience and Nanotechnology, 17(12): 8946-8951.

Gunes I, 2013. Wear Behavior of Plasma Paste Boronized of AISI 8620 Steel with Borax and $\mathrm{B}_{2} \mathrm{O}_{3}$ Paste Mixtures. Journal of Materials Science and Technology, 29: 662-668.

Gunes I, Erdogan M, Çelik AG, 2014. Corrosion Behavior and Characterization of Plasma Nitrided and Borided AISI M2 Steel. Materials Research, 17(3): 612-618.

Günen A, Karahan İH, Karakaş MS, Kurt B, Kanca Y, Çay VV, Yıldız M, 2020. Properties and Corrosion Resistance of AISI H13 Hot-Work Tool Steel with Borided $\mathrm{B}_{4} \mathrm{C}$ Powders. Metals and Materials International, 26: 1329-1340.

Günen A, Kurt B, Orhan N, Kanca E, 2014. The Investigation of Corrosion Behavior of Borided AISI 304 Austenitic Stainless Steel with Nanoboron Powder. Protection of Metals and Physical Chemistry of Surfaces, 50(1): 104-110.

Kayali Y, 2015. Investigation of Diffusion Kinetics of Borided AISI P20 Steel in Microwave Furnace. Vacuum, 121, 129-134.

Kayali Y, Barut N, Talas S, Buyuksagis A, 2018. Investigation of Corrosion and Wear Behavior of Borided AISI P20 Steel in Micro-Wave Furnace. Materials Research Express, 6(1), 1-22.

Kayali Y, Buyuksagis A, Yalcin Y, 2013. Corrosion and Wear Behaviors of Boronized AISI 316L Stainless Steel. Metals and Materials International, 19(5), 1053-1061.

Mejía-Caballero I, Martinez-Trinidad J, Palomar-Pardavé M, Romero-Romo M, Herrera-Hernández H, Herrera-Soria O, Campos-Silva I, 2014. Electrochemical Evaluation of Corrosion on Borided and NonBorided Steels Immersed in $1 \mathrm{M} \mathrm{HCl}$ Solution. Journal of Materials Engineering and Performance, 23(8): 2809-2818.

Mertgenc E, Kesici OF, Kayali Y, 2019. Investigation of Wear Properties of Borided Austenitic Stainless Steel

Different Temperatures and Times. Materials Research Express, 6(7): 1-8.

Ozbek I, Bindal C, 2002. Mechanical Properties of Boronized AISI W4 Steel. Surface and Coatings Technology, 154: 14-20.

Ozbek I, Konduk BA, Bindal C, Ucisik AH, 2002. Characterization of Borided AISI 316L Stainless Steel Implant. Vacuum, 65(3-4): 521-525.

Sap S, Hazar H, Sap E, 2020. Investigation of the Effect of $\mathrm{Cr}_{3} \mathrm{C}_{2}$ Coating by Plasma Spray Process on Exhaust Pipe of a Diesel Engine. Iğdır Journal of the Institute of Science and Technology, 10(1): 499508.

Shen Y, Li W, Li T, 2011. Microwave-Assisted Synthesis of $\mathrm{BaWO}_{4}$ Nanoparticles and Its Photoluminescence Properties. Materials Letters, 65(19-20): 2956-2958.

Von Matuschka AG, 1980. Boronizing. Carl Hanser Verlag, München.

Yönetken A, 2019. Investigation of the Production and Mechanical Properties of Silicon Carbide-Reinforced Composites. Iğdır Journal of the Institute of Science and Technology, 9(3): 1551-1558. 